\title{
PENGEMBANGAN MODUL BERBASIS MATEMATIKA REALISTIK BERCIRIKAN BUDAYA INDONESIA
}

\author{
Agung D. Ismail ${ }^{1}$, Anis F. Jamil ${ }^{2}$ \\ ${ }^{1}$ Universitas Muhammadiyah Malang \\ deddy@umm.ac.id \\ ${ }^{2}$ Universitas Muhammadiyah Malang \\ anisfarida@umm.ac.id
}

\begin{abstract}
ABSTRAK
Salah satu dampak negatif globalisasi adalah berkurangnya cinta terhadap budaya pada generasi muda. Meningkatkan kecintaan terhadap budaya pada generasi muda dapat dilakukan pada pembelajaran matematika. Matematika realistik menghubungkan pembelajaran matematika dengan aktivitas kehidupan sehari-hari. Matematika realistik bercirikan budaya Indonesia dituangkan dalam modul dengan tujuan selain untuk pembelajaran matematika namun juga dapat menambah pengetahuan mahasiswa mengenai budaya Indonesia. Penelitian ini bertujuan untuk mengembangkan modul berbasis matematika realistik bercirikan budaya Indonesia yang berkategori valid dan praktis. Instrumen yang digunakan pada penelitian ini adalah lembar validasi dan lembar angket respon mahasiswa. Lembar validasi untuk memperoleh data kevalidan modul sedangkan lembar angket respon mahasiswa digunakan untuk memperoleh data kepraktisan modul. Metode yang digunakan pada penelitian ini melalui tiga tahapan yakni tahap pendefinisian, tahap perancangan, dan tahap pengembangan. Penelitian dan pengembangan ini menghasilkan modul berbasis matematika realistik bercirikan budaya Indonesia yang valid dan praktis. Valid diperoleh dari data analisis lembar validasi yang diisi oleh validator ahli. Kepraktisan modul diperoleh dari hasil angket respon mahasiswa yang menunjukkan respon positif.
\end{abstract}

Kata Kunci: modul, bahan ajar, matematika realistik, budaya Indonesia

\begin{abstract}
One of the negative effects of globalization is the reduced love for culture in the younger generation. Increasing the love of culture in the younger generation can be done in mathematics learning. Realistic mathematics connects mathematics learning with daily life activities. Realistic mathematics characterized by Indonesian culture is contained in modules with the aim of learning mathematics and also can increase students' knowledge about Indonesian culture. This study aims to develop modul based on realistic mathematical characterized by Indonesian culture that is valid and practical. The instruments used in this study were validation sheets and student response questionnaire sheets. Validation sheet to obtain module validity data while student response questionnaire sheets are used to obtain module practicality data. The method used in this study is through three stages, namely the stage of defining, designing, and developing. This research and development produces modul based on realistic mathematical characterized by Indonesian culture that is valid and practical. Valid is obtained from the data analysis sheet validation filled by expert validators. The practicality of the
\end{abstract}


module was obtained from the results of the student response questionnaire which showed a positive response.

Keywords: modul, teaching material, realistic mathematics, Indonesian culture

Format Sitasi: Ismail, A.D., \& Jamil, A.F. (2019). Pengembangan Modul Berbasis Matematika Realistik Bercirikan Budaya Indonesia. Kalamatika: Jurnal Pendidikan Matematika, 4(2), 177-192.

Penyerahan Naskah: 25 Juli 2019 || Revisi: 25 November 2019 || Diterima: 28 November 2019

\section{PENDAHULUAN}

Pembelajaran matematika merupakan suatu kegiatan proses pemahaman materi matematika pada mahasiswa. Banyak pendekatan, metode dan strategi yang digunakan untuk membantu mahasiswa dalam memahami konsep tersebut. Abadi (2018) menyebutkan bahwa berdasarkan hasil penelitian yang telah dilakukan, mahasiswa mengalami kesulitan dalam pemahaman konsep matematika. Sucipto \& Mauliddin (2017) juga menyebutkan bahwa mahasiswa mengalami kesulitan dalam pemahaman konsep, penerapan atau aplikasi dalam pemecahan masalah matematika. Dalam pembelajarannya mahasiswa juga dituntut untuk mandiri dalam mamahami konsep matematika sesuai Undang-undang RI No. 12 tahun 2012 tentang Pendididikan Tinggi.

Mahasiswa membutuhkan bantuan dalam belajar mandiri. Salah satu yang dapat membantu adalah modul pembelajaran. Modul merupakan salah satu bahan ajar yang bertujuan untuk memudahkan penyampaian konsep pada mahasiswa secara tidak langsung. Modul dapat dibuat secara kreatif tanpa adanya batasan. Modul dapat membantu mahasiswa untuk mengevaluasi atau mengukur kemampuannya. Untuk menyusun modul Daryanto (2013) menyebutkan terdapat empat karakteristik yang perlu diperhatikan dalam penyusuan modul yaitu Self Instructional, Self Contained, Stand Alone, dan Adaptif User Friendly. Modul adalah bahan ajar yang dibuat untuk digunakan mahasiswa dalam pembelajaran secara mandiri dan tersusun dengan sistematis (Kusuma \& Harimurti, 2017). Modul yang dapat membantu mahasiswa adalah modul yang berisi tentang materi yang disusun dengan mudah dicerna atau dipahami oleh mahasiswa. Materi yang dikaitkan dengan kehidupan sehari-hari atau yang berkaitan dengan lingkungan mahasiswa. Pembelajaran berbasis matematika realistik dapat dijadikan alternatif dalam membantu pemahaman konsep. Menurut (Lasmiyati \& Harta, 2014) pembelajaran yang menggunakan modul dapat memiliki manfaat sebagai berikut: 1) mahasiswa dapat mengetahui kelebihan dan kekurangannya sehingga dapat melakukan 
evaluasi dan perbaikan diri, 2) mahasiswa dapat belajar secara terarah karena modul dibuat berdasarkan tujuan pembelajaran yang jelas, 3) desain modul dapat dibuat menarik dan mudah dipelajari sesuai kebutuhan mahasiswa, 4) modul dibuat agar dapat dipelajari mahasiswa dengan cara dan kecepatan yang berbeda-beda, 5) meningkatkan kerjasama dalam memahami materi antar mahasiswa, dan 6) remidi dapat dilakukan setelah mahasiswa melakukan evaluasi terhadap dirinya.

Pendekatan pembelajaran yang dipakai adalah pembelajaran matematika realistik. Pembelajaran realistik adalah pendekatan pembelajaran matematika yang merupakan aktifitas manusia yang ditekankan pada kegiatan mahasiswa untuk mencari, menemukan dan mengembangkan pengetahuan yang diperlukan (Gravemeijer, 1994). Gravemeijer (1994) mengemukakan bahwa Matematika Realistik merupakan suatu pendekatan yang memiliki prinsip: 1) penemuan terbimbing, 2) fenominalogi didaktis, dan 3) membangun sendiri model. Hal tersebut maksudnya adalah mahasiswa menyelesaikan suatu masalah matematika dengan menggunakan masalah yang realistik yang berarti masalah di kehidupan sehari-hari mereka. Melalui masalah realistik, dosen membimbing mahasiswa untuk memodelkan ke dalam bentuk matematika dan menemukan konsep matematika. Fitriani \& Maulana (2016) mengatakan tujuan dari pendekatan matematika realistik adalah mahasiswa memiliki pengalaman belajar yang bermakna sehingga memiliki sikap positif terhadap matematika. Pendekatan matematika realistik berasal dari suatu teori yang bernama Realistic Mathematics Education (RME) yang menganggap matematika berasal dari aktivitas manusia sehingga dapat dihubungkan dengan konteks kehidupan sehari-hari mahasiswa untuk mengembangkan konsep matematika dan menerapkannya.

Agustin (2011) menyatakan bahwa karena adanya pengaruh globalisasi memiliki dampak negatif yaitu menurunkan kecintaan terhadap budaya pada generasi muda. Hal ini terlihat banyak generasi muda tidak mengetahui semua budaya yang dimiliki oleh bangsa Indonesia. Sebagai warga Negara Indonesia sudah menjadi kewajiban untuk melestarikan budaya, karena budaya merupakan kekayaan bangsa yang tidak ternilai harganya. Berdasarkan permasalahan yang telah diuraikan maka tujuan penelitian adalah mengembangkan modul berbasis pembelajaran matematika realistik bercirikan Budaya Indonesia. Diharapkan melalui modul ini, mahasiswa dapat memahami konsep dari materi yang dipelajari serta meningkatkan 
pengetahuannya terkait Budaya Indonesia sehingga meningkatkan kecintaan terhadap Budaya Indonesia.

\section{METODE PENELITIAN}

Penelitian yang dilakukan berjenis penelitian pengembangan. Model pengembangan yang digunakan adalah model 3D yang merupakan modifikasi dari model 4D oleh Thiagarajan. Model 3D terdiri dari tahapan: 1) Tahap Pendefinisian (Define), 2) Tahap Perancangan (Design), dan Tahap Pengembangan (Develop). Penelitian ini bertujuan untuk menghasilkan m

Modul berbasis matematika realistik bercirikan Budaya Indonesia yang valid dan praktis. Instrumen penelitian yang digunakan adalah lembar validasi modul dan lembar angket respon mahasiswa. Lembar validasi modul digunakan untuk mendapatkan data kevalidan modul dan lembar angket respon mahasiswa untuk medapatkan data kepraktisan modul.

Tahap Pendefinisian (Define) adalah tahap menetapkan syarat-syarat perancangan modul sehingga sesuai dengan kebutuhan. Terdapat tiga hal yang ditetapkan pada tahapan pendefinisian ini yaitu analisis konsep, analisis tugas, dan perumusan tujuan pembelajaran. Analisis konsep dilakukan dengan mengidentifikasi materi pembelajaran yaitu materi himpunan dengan bercirikan pendekatan matematika realistik tentang Budaya Indonesia. Analisis tugas dilakukan dengan mengidentifikasi tugas mahasiswa yang bercirikan Budaya Indonesia. Tujuan pembelajaran dirumuskan dengan: 1) mahasiswa dapat menjelaskan pengertian himpunan, 2) mahasiswa dapat menentukan contoh dan bukan contoh himpunan, 3) mahasiswa dapat menyelesaikan permasalahan berkaitan dengan operasi himpunan khususnya irisan dan gabungan, dan 4) mahasiswa dapat menambah pengetahuan mengenai Budaya Indonesia.

Tahap Perancangan (Design) bertujuan untuk merancang format modul. Format modul direncanakan memiliki unsur-unsur berikut: 1) Cover, 2) Daftar Isi, 3) Materi Himpunan, 4) Materi Irisan dan Contoh Soal, 5) Materi Gabungan dan Contoh Soal, dan 6) Latihan Soal.

Tahap Pengembangan (Develop) ditujukan untuk menghasilkan modul dan dilanjutkan oleh kegiatan validasi modul. Modul dikembangkan sesuai dengan perencanaan yang telah dibuat. Ketika validator ahli menyatakan modul mendapatkan hasil valid maka dilanjutkan tahap uji coba. Selanjutnya, angket respon dibagikan kepada mahasiswa yang telah menggunakan modul berbasis realistik bercirikan Budaya Indonesia pada pembelajaran. 


\section{HASIL DAN PEMBAHASAN}

\section{Tahap Pendefinisian (Define)}

Pengembangan modul dilakukan dengan tahapan awal yaitu tahap pendefinisian. Tahap pendefinisian dilakukan dengan analisis konsep, analisis tugas, dan perumusan tujuan pembelajaran. Pada analisis konsep, materi pembelajaran yang ditentukan adalah himpunan khususnya pada operasi irisan dan gabungan. Materi himpunan yang dibahas diawali dengan cerita Budaya Indonesia sebagai contoh tarian tradisional dan candi-candi. Memberikan contoh cerita kumpulan budaya Indonesia yang dapat dikatakan himpunan dan bukan himpunan. Selanjutnya mahasiswa dituntun untuk menentukan definisi himpunan secara mandiri dan diberikan definisi himpunan yang benar. Pada analisis tugas, ditentukan masalah yang akan menjadi latihan soal yang diberikan kepada mahasiswa. Latihan soal memiliki karakteristik matematika realistik dan pengetahuan pengetahuan budaya. Tujuan pembelajaran dirumuskan dan dituliskan pada modul sebagai berikut: 1) mahasiswa dapat menjelaskan pengertian himpunan, 2) mahasiswa dapat menentukan contoh dan bukan contoh himpunan, 3) mahasiswa dapat menyelesaikan permasalahan berkaitan dengan operasi himpunan khususnya irisan dan gabungan, dan 4) mahasiswa dapat menambah pengetahuan mengenai Budaya Indonesia. Kegiatan yang dilakukan pada tahapan pendefinisian juga sejalan dengan penelitian pengembangan sebelumnya. Kurniawan et al. (2017) pada penelitiannya menentukan tahapan pendefinisian antara lain: 1) analisis awal-akhir, 2) analisis materi, 3) analisis tugas, dan 4) spesifikasi tujuan pembelajaran. Dewi \& Akhlis (2016) menyatakan kegiatan yang dilakukan pada tahap pendefinisian yaitu menentukan tujuan pembelajaran, menentukan metode pelaksanaan, memilih media, membuat draft RPP, membuat draft lembar kerja siswa, membuat draft soal tes hasil belajar, dan draft instrumen penilaian dan angket.

\section{Tahap Perancangan (Design)}

Tahapan perancangan (Design) yang telah dilakukan adalah pertama pembuatan cover modul. Untuk menarik pembaca modul dirancang dengan menggunakan gambar yang menarik serta warna dan jenis font yang sesuai. Desain awal cover dibuat dengan sederhana seperti pada Gambar 1. Pada bagian cover ini berisi tentang tema modul yaitu Modul Matematika Berbasis Kontekstual Bercirikan Budaya Indonesia. Materi pada modul adalah himpunan. Pada cover juga diberikan gambar Budaya Indonesia agar menarik pembaca. Bagian bawah 
modul diberikan kolom identitas untuk mahasiswa yang terdiri dari nama, NIM (Nomor Induk Mahasiswa) dan kelas.

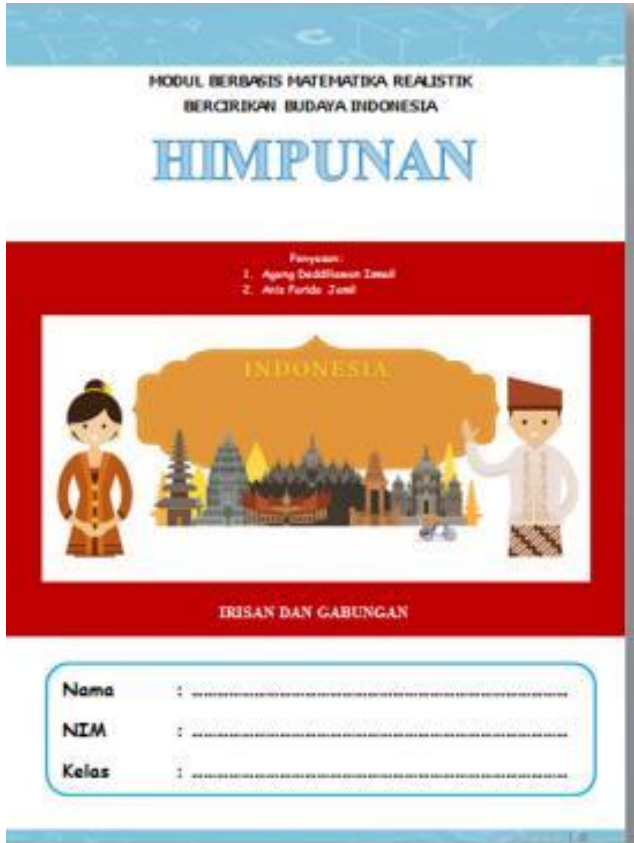

Gambar 1. Cover pertama

Perancangan cover dilakukan dengan melakukan dua kali. Perubahan desain cover ini berdasarkan dari feedback angket respon mahasiswa.

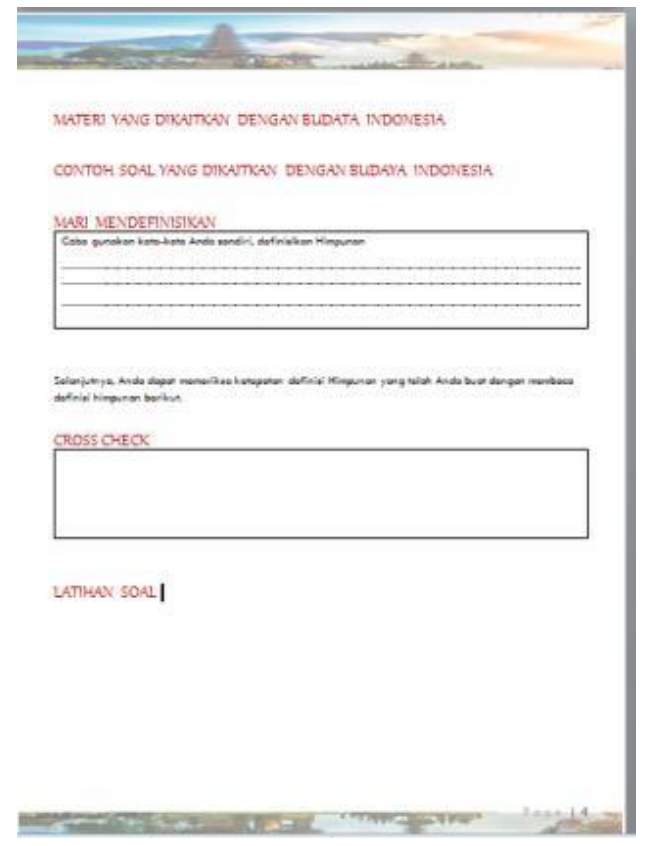

Gambar 2. Template isi Modul 
Untuk mengembangkan isi modul, di awal kegiatan dirancang sebuah kerangka atau tamplate yang nantinya dapat digunakan untuk menyusun modul yang sistematis seperti pada Gambar 2. Terdapat lima sub materi pada isi modul diantaranya adalah materi, contoh soal yang dikembangkan dengan mengaitkan Budaya Indonesia. Materi serta contoh soal dikemas dengan menggunakan cerita berkenaan tentang Budaya Indonesia disertai dengan gambargambar sebagai informasi bagi mahasiswa. Diharapkan dengan rancangan materi tersebut memudahkan mahasiswa dalam memahami materi. Hal ini sejalan dengan penelitian yang dilakukan (Junaedi, Asikin, \& Masrukan, 2015) yang menyusun pembelajaran dengan pendekatan RME yang disesuaikan dengan konteks sehari-hari mahasiswa tentang karakter dan konservasi dapat memudahkan mahasiswa dalam menyusun proposal penilitian.

Sub materi selanjutnya adalah mari mendefinisikan yang berupa kolom untuk mahasiswa agar dapat mendefinisikan materi sesuai dengan bahasa dan pemahamannya masing-masing. Sub materi ke empat adalah cross check, pada bagian ini mahasiswa akan diajak untuk mengecek kembali tentang definisi yang telah mereka sebutkan dengan definisi yang sesuai dengan teori. Sub materi terakhir berisi latihan soal yang berisi kumpulan soal evaluasi yang berisi tentang penguatan konsep dan soal dengan mengangkat Budaya Indonesia.

\section{Tahap Pengembangan (Develop)}

Sebelum mengembangkan modul, pada tahapan pengembangan (develop) dibuat lembar validasi dan lembar respon mahasiswa. Lembar respon mahasiswa berisi tiga pertanyaan utama mengenai kejelasan modul, kemudahan dalam mempelajari modul dengan berbasis budaya Indonesia, dan ketertarikan mempelajari modul. Selanjutnya, modul dikembangkan sesuai dengan yang direncanakan pada tahapan perencanaan (design). Gambar 3 merupakan cover modul yang telah dibuat. 


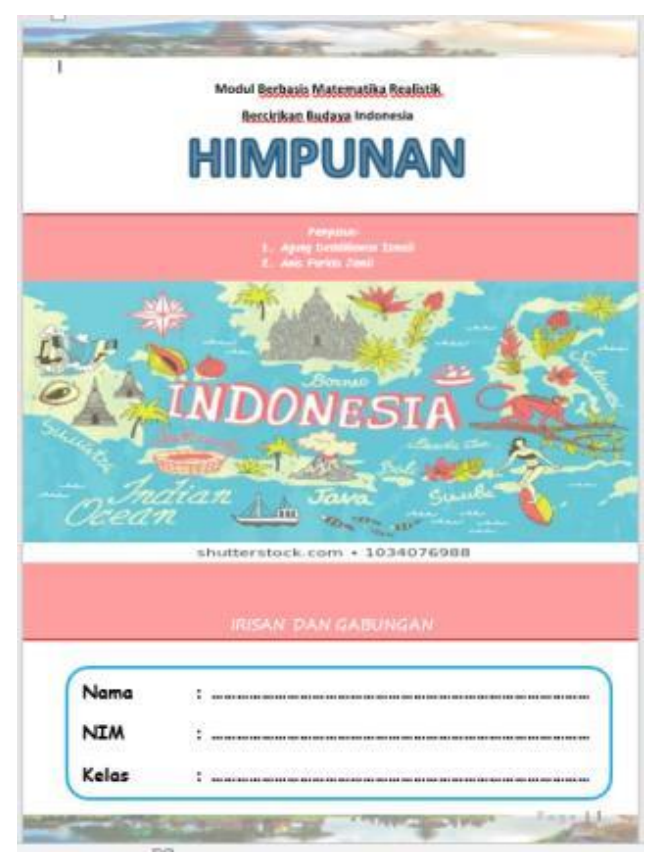

Gambar 3. Cover Modul Berbasis Matematika Realistik Bercirikan Budaya Indonesia

Capaian pembelajaran disesuaikan dengan silabus matakuliah yang diajarkan. Pada modul tertuliskan capaian pembelajaran yaitu memahami konsep himpunan dan operasioperasinya secara mandiri dan bertanggung jawab. Gambar 4 merupakan lembar modul tentang capaian pembelajaran.

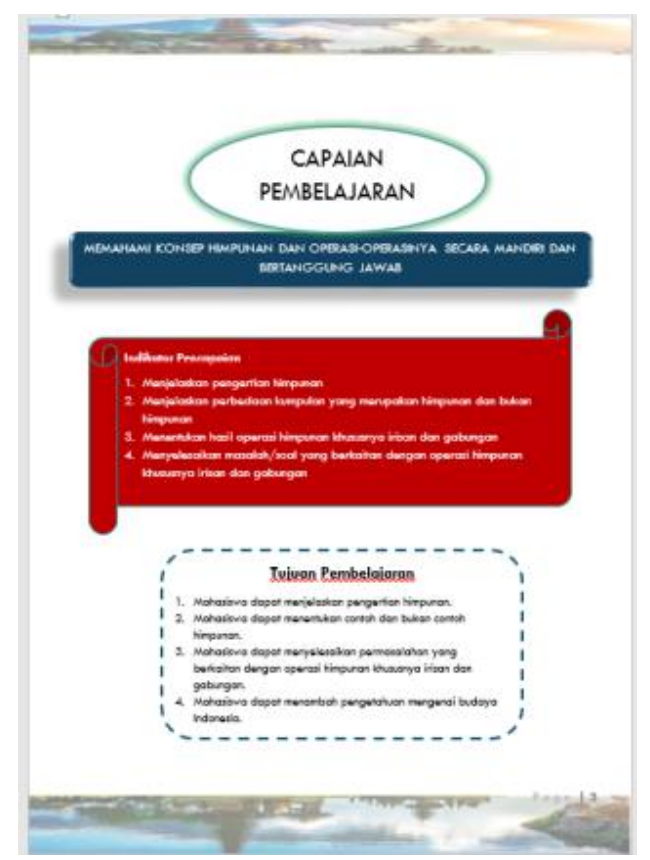

Gambar 4. Lembar Penjelasan Capaian, Indikator, dan Tujuan Pembelajaran 
Pembahasan materi pada modul diawali dengan masalah matematika tentang contoh kumpulan yang dapat disebut himpunan dan kumpulan yang bukan himpunan yang dituliskan dengn cerita Budaya Indonesia. Modul dilengkapi dengan gambar-gambar Budaya Indonesia dan penjelasan terkait budaya tersebut. Gambar 5 merupakan bagian modul tentang penjelasan materi pada memberikan contoh Himpunan.

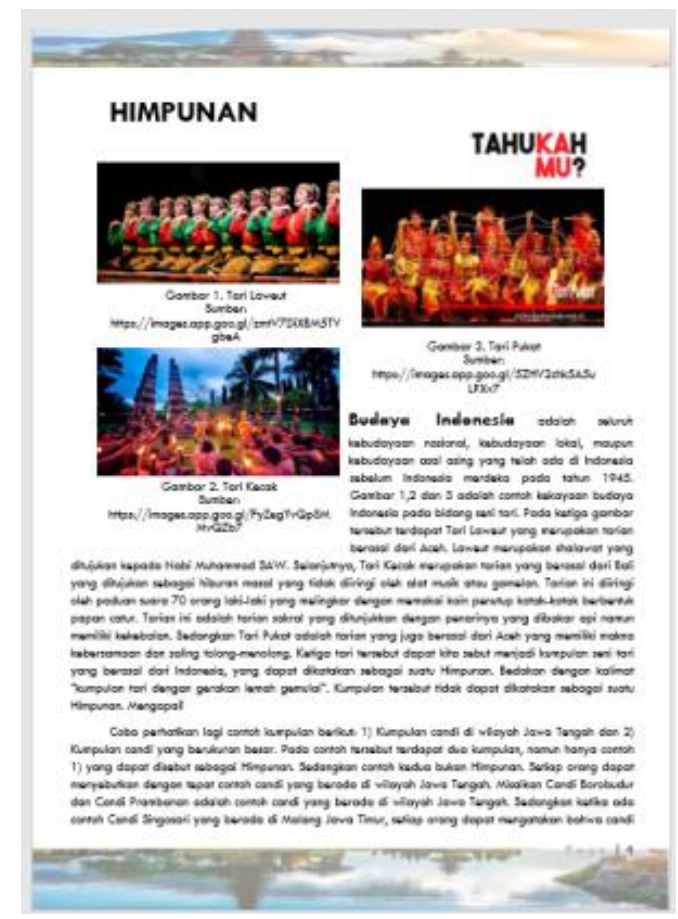

Gambar 5. Contoh Modul pada Penjelasan Materi Contoh Himpunan

Pemberian contoh dan bukan contoh maupun penjelasan materi diharapkan dapat menuntun mahasiswa untuk dapat mendefinisikan secara mandiri dengan bahasanya sendiri. Gambar 6 merupakan contoh lembar modul yang menuntun mahasiswa untuk dapat mendefinisikan materi yang telah dibahas. 


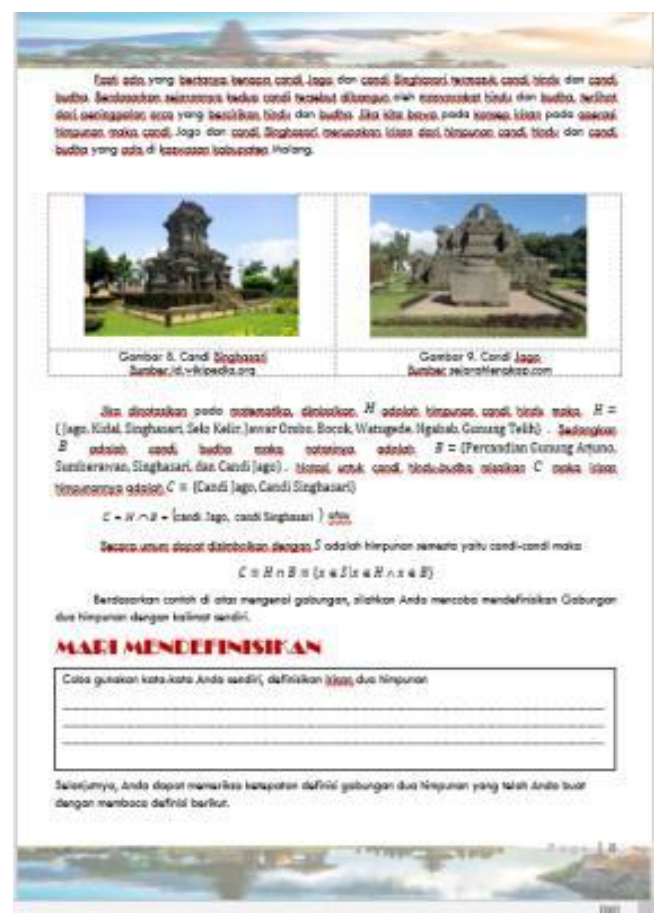

Gambar 6. Contoh Lembar Modul Mahasiswa dalam Menarik Definisi

Setelah penjelasan materi, mahasiswa juga diberikan contoh soal yang lengkap dengan solusinya. Berikut contoh tampilan modul pada bagian contoh soal.

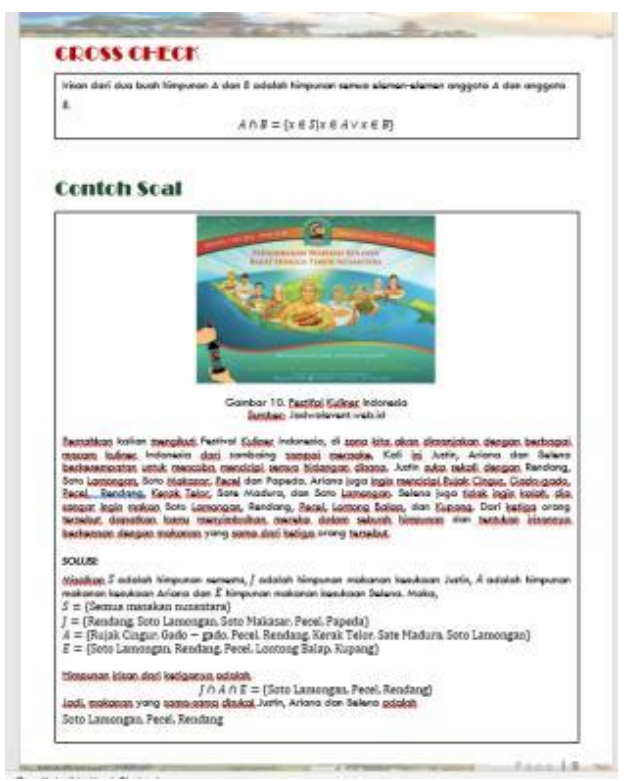

Gambar 7. Contoh Lembar Modul yang Berisi Contoh Soal

Pada bagian akhir modul, diberikan latihan soal sehingga mahasiswa dapat melatih kemampuannya dalam memahami materi himpunan khususnya operasi irisan dan gabungan. Gambar 8 merupakan lembar latihan soal pada modul. 


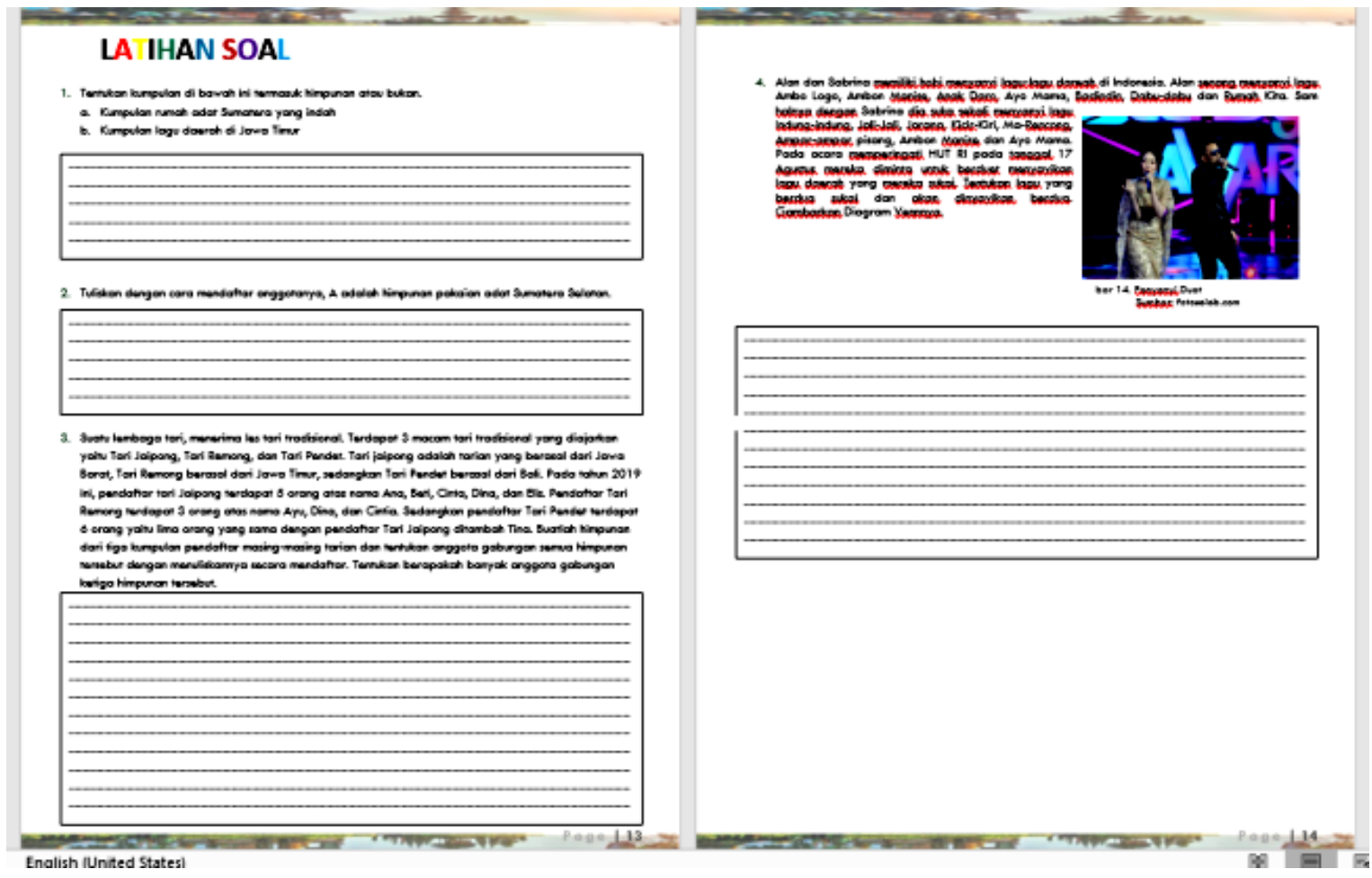

Gambar 8. Contoh Lembar Modul yang Berisi Latihan Soal

Modul yang telah jadi divalidasi oleh validator ahli dengan memperoleh hasil yang valid. Hal ini berarti bahwa modul dapat diuji cobakan. Setelah modul diuji cobakan kepada mahasiswa, selanjutnya mahasiswa diberikan angket untuk mengetahui respon mahasiswa setelah menggunakan modul berbasis matematika realistik bercirikan Budaya Indonesia. Hasil respon mahasiswa menunjukkan respon positif yakni dengan skor diatas 2 . Hal tersebut berarti mahasiswa merasa mudah dan tertarik mempelajari modul serta menambah pengetahuan mereka mengenai Budaya Indonesia. Gambar 9 memperlihatkan contoh pekerjaan mahasiswa dalam menggunakan modul. 


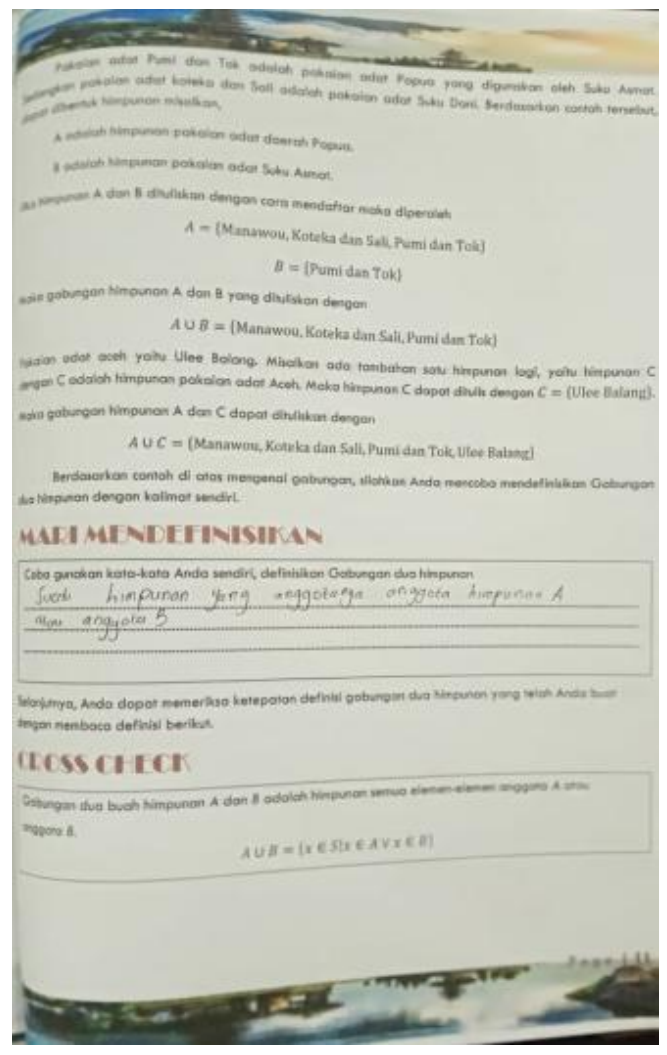

Gambar 9. Contoh Pekerjaan Mahasiswa Menggunakan Modul

Selanjutnya Gambar 10 memperlihatkan contoh pekerjaan mahasiswa dalam menyelesaikan latihan soal

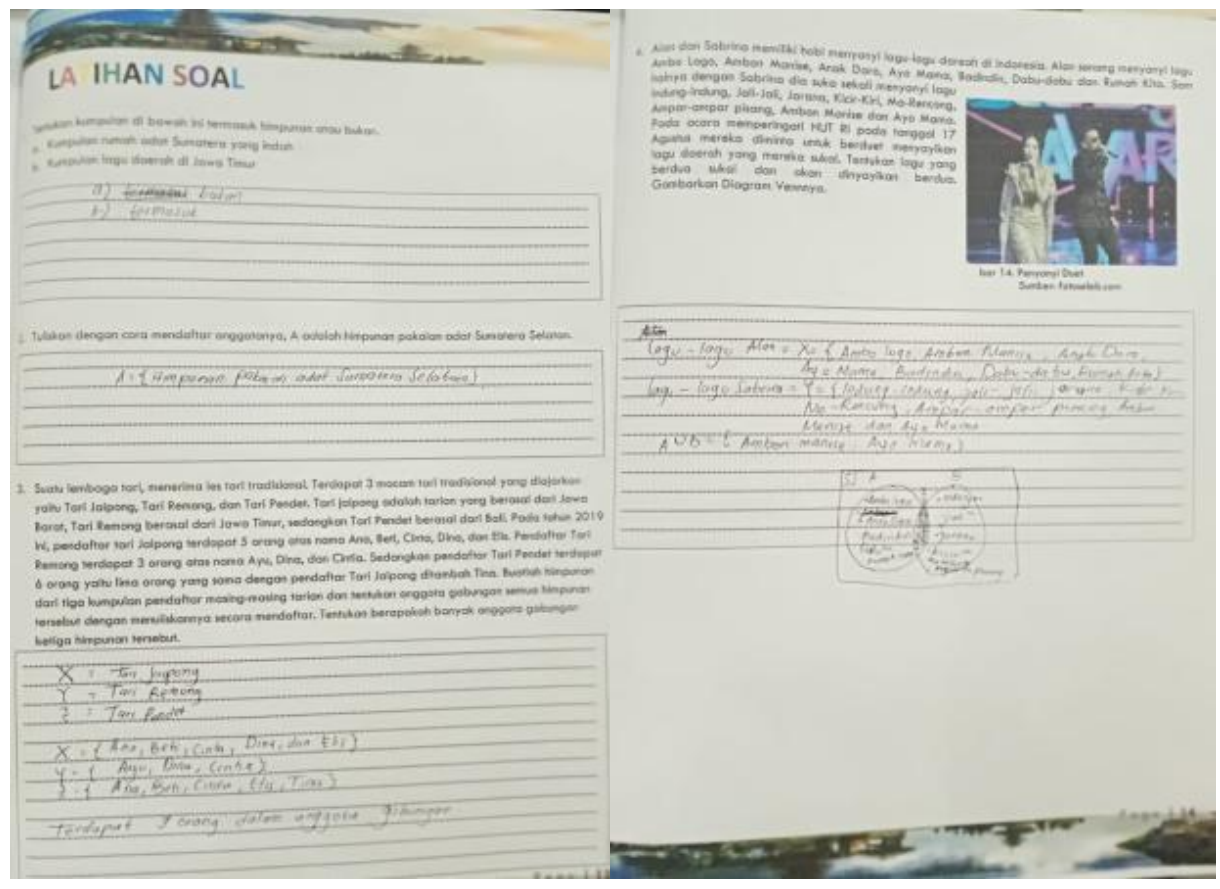

Gambar 10. Contoh Pekerjaan Mahasiswa dalam Menyelesaikan Latihan Soal 
Gambar 11 merupakan contoh komentar mahasiswa pada lembar angket respon mahasiswa.

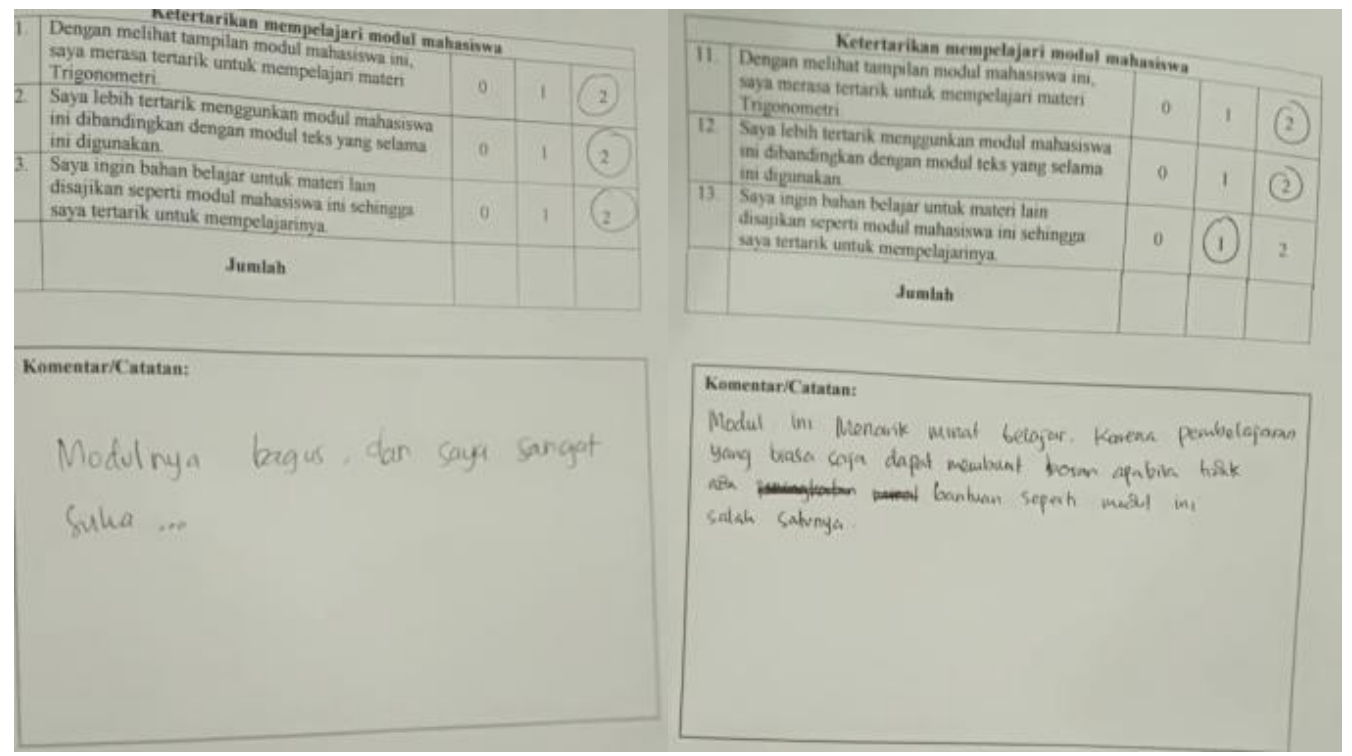

Gambar 11. Contoh Komentar Mahasiswa pada Lembar Angket Respon Mahasiswa

Penggunaan RME sebagai pendekatan dalam menyusun modul memudahkan mahasiswa dalam menyelesaikan soal latihan. Hal ini sejalan dengan penelitian yang dilakukan oleh (Irawati, 2016) yang menyatakan bahwa pendekatan RME lebih baik dari pendekatan konvensional dalam meningkatkan kemampuan pemahaman matematis. Selain itu, Pada penelitian lain yang dilakukan oleh (Sarwoedi, Marinka, Febriani, \& Wirne, 2018) dimana matematika disajikan dalam suatu budaya yang disebut dengan Etnomatematika juga dapat meningkatkan kemampuan pemahaman matematika dan peningkatan pengetahuan siswa terkait budaya. Selain itu, (Supriadi, Arisetyawan, \& Tiurlina, 2016) mengintegrasikan pembelajaran matematika berbasis budaya mendapatkan kesan postif bagi siswa dalam melakukan refleksi pembelajaran.

\section{KESIMPULAN}

Pengembangan modul berbasis matematika realistik bercirikan budaya Indonesia dilakukan dengan 3 tahapan yaitu tahap pendefinisian, tahap perancangan, dan tahap pengembangan. Modul yang telah dikembangkan berkriteria valid sehingga dapat digunakan untuk uji coba. Selain itu, modul juga mendapatkan respon positif dari mahasiswa sehingga dapat dikatakan modul bersifat praktis. 


\section{REKOMENDASI}

Rekomendasi untuk penelitian lebih lanjut terkait pengembangan modul berbasis matematika realistik bercirikan Budaya Indonesia dapat dikembangkan lebih luas terhadap cakupan materinya.

\section{UCAPAN TERIMAKASIH}

Ucapan terimakasih yang sebesar-besarnya disampaikan kepada Universitas Muhammadiyah Malang yang telah memberikan dukungan berupa fasilitas yang digunakan pada penelitian terutama dukungan dana penelitian.

\section{REFERENSI}

Abadi, A. P. (2018). Analisis Pemahaman Konsep Matematika Mahasiswa dalam Menyelesaikan Soal Teori Grup kemampuan yang mengharapkan siswa mahasiswa pada program sarjana dan mahasiswa yang akan melanjutkan studi teori-teori dasar dan pembuktian menyebabkan mahasiswa senantiasa. Jurnal of Medives, 2(2), 235-244.

Agustin, D. (2011). Penurunan Rasa Cinta Budaya Dan Nasionalisme Generasi Muda Akibat Globalisasi. Jurnal Sosial Humaniora, 4(2), 177-185. Retrieved from http://www.iptek.its.ac.id/index.php/jsh/article/view/632

Daryanto. (2013). Menyusun Modul. Yogyakarta: Gava Media.

Dewi, Novi Ratna., Akhlis, I. (2016). Pengembangan Perangkat Pembelajaran IPA Berbasis Pendidikan Multikultural Menggunakan Permainan untuk Mengembangkan Karakter Siswa. Unnes Science Education Journal, 5(2), 1253- 1260. https://doi.org/http://dx.doi.org/10.15294/usej.v3i2.3349

Fitriani, K., \& Maulana, -. (2016). Meningkatkan Kemampuan Pemahaman Dan Pemecahan Masalah Matematis Siswa Sd Kelas V Melalui Pendekatan Matematika Realistik. Mimbar Sekolah Dasar, 3(1), 40-52. https://doi.org/10.17509/mimbar-sd.v3i1.2355

Gravemeijer, K. (1994). Educational development and developmental research in mathematics education. Journal for research in Mathematics Education, 443-471. 
Irawati, R. (2016). Pengaruh Pendekatan Realistic Mathematics Education Terhadap Kemampuan Koneksi Dan Representasi Matematis Siswa Pada Materi Perbandingan Dan Skala, 1(1), 571-580. https://doi.org/10.17509/jpi.v1i1.3055

Junaedi, I., Asikin, M., \& Masrukan, M. (2015). Penerapan Realistic Mathematics Education (RME) dengan Konteks Karakter dan Konservasi untuk Meningkatkan Kemampuan Mahasiswa dalam Menyusun Proposal Penelitian. Kreano, Jurnal Matematika KreatifInovatif, 6(2), 177. https://doi.org/10.15294/kreano.v6i2.4988

Kurniawan, D., Dewi, S. V., Pendidikan, J., Fakultas, M., Dan, K., Pendidikan, I., \& Siliwangi, U. (2017). Pengembangan Perangkat Pembelajaran Dengan Media Screencast- O-Matic Mata Kuliah Kalkulus 2 Menggunakan Model 4-D Thiagarajan. Jurnal Siliwangi, 3(1).

Kusuma, Kevin Patria \& Harimurti, L. (2017). Penerapan Modul Penggunaan Fitur Activity Wizard pada Cisco Packet Tracer Sebagai Media Evaluasi Pembelajaran pada Mata Pelajaran Rancang Bangun Jaringan. It-Edu, 2(01), 67-73.

Lasmiyati, Harta, I. (2014). Pengembangan Modul Pembelajaran untuk Meningkatkan Pemahaman Konsep dan Minat SMP. Pythagoras: Jurnal Pendidikan Matematika, 9(2), 161-174. https://doi.org/10.21831/pg.v9i2.9077

Sarwoedi, S., Marinka, D. O., Febriani, P., \& Wirne, I. (2018). Efektifitas Etnomatematika dalam Meningkatkan Kemampuan Pemahaman Matematika Siswa Pendahuluan Pengertian Etnomatematika. Jurnal Pendidikan Matematika Raflesia, 03(02), 101-106.

Sucipto, L., \& Mauliddin, M. (2017). Analisis Kesulitan Belajar Mahasiswa Dalam Memahami Konsep Bilangan Real. Beta Jurnal Tadris Matematika, 9(2), 197. https://doi.org/10.20414/betajtm.v9i2.37

Supriadi, Arisetyawan, A., \& Tiurlina. (2016). Mengintegrasikan Pembelajaran Matematika Berbasis Budaya Banten Pada Pendirian Sd Laboratorium Upi Kampus Serang. Mimbar Sekolah Dasar, 3(1), 1-18. https://doi.org/10.17509/mimbar-sd.v3i1.2510 
Ismail \& Jamil 192 